\title{
ÇİMENTO ESASLI KÖPÜK SIVANIN FIZİKSEL, MEKANİK VE TERMAL ÖZELLİKLERİ
}

\author{
Metin DAVRAZ1 ${ }^{*}$, Yasin GÖKÇE², Murat KORU ${ }^{3}$, Ali Ekrem AKDAĞ ${ }^{4}$
}

${ }^{1}$ Isparta Uygulamalı Bilimler Üniversitesi Senirkent Meslek Yüksekokulu, İnşaat Bölümü, Isparta, Türkiye ${ }^{2}$ Süleyman Demirel Üniversitesi Fen Bilimleri Enstitüsü, İnşaat Müh. Anabilim Dalı, Isparta, Türkiye ${ }^{3}$ Isparta Uygulamalı Bilimler Üniversitesi Teknoloji Fakültesi, Makine Mühendisliği Bölümü, Isparta, Türkiye ${ }^{4}$ Isparta Uygulamalı Bilimler Üniversitesi Teknik Bilimler MYO, Optisyenlik Programı, Isparta, Türkiye

\begin{tabular}{|c|c|}
\hline Anahtar Kelimeler & $\tilde{\mathbf{O} z}$ \\
\hline $\begin{array}{l}\text { Çimento Esaslı Köpük Sıva, } \\
\text { Isı Yalıtımı, } \\
\text { Eşdeğer Kalınlık, } \\
\text { Ekonomiklik. }\end{array}$ & $\begin{array}{l}\text { Ülkemizde bina yalıtımında EPS ve XPS ıSı yalıtım levhaları halen yaygın olarak } \\
\text { kullanılmaktadır. Ancak, bu malzemelerin düşük yangın dirençleri nedeniyle son } \\
\text { yıllarda yüksek katlı binalarda kullanımı sınırlandırılmıştır. Bu tür yapılarda } \\
\text { camyünü-taşyünü levhalar ve ısı yalıtım sıvaları gibi A sınıfı yangın dayanımına } \\
\text { sahip malzemelerin kullanımı mümkündür. Ancak camyünü - taşyünü levhalarda } \\
\text { su emme ve yüksek birim maliyetler önemli sorunlardır. Türkiye'de "ısı yalıtım } \\
\text { sıvası" adı altında çok farklı marka ve türde ürün mevcuttur. Bu ürünlerin ısı } \\
\text { iletkenlik açısından sorunlu olduğu da bilinmektedir. Bu çalışmada, yüksek } \\
\text { performanslı, ekonomik ve kolay uygulanabilen farklı bir ürünün geliştirilmesi } \\
\text { amaçlanmıştır. Köpük sıvada bağlayıcı olarak Portland çimentosu ve kireç, hafif } \\
\text { agrega olarak genleştirilmiş perlit, kaplı perlit, cam küre ya da diyatomit } \\
\text { kullanılmıştır. Köpük yoğunluğu } 85 \text { g/L dir. Tüm karışımlarda s/b oranı }(0.5) \\
\text { sabittir. Üretilen numuneler üzerinde birim hacim kütle, basınç ve eğilme } \\
\text { dayanımları, kılcal su emme, ısıl iletkenlik deneyleri yürütülmüştür. Köpük sıva } \\
\text { numunelerinin kuru yoğunlukları } 250 \mathrm{~kg} / \mathrm{m}^{3} \text {, } 28 \text { günde basınç dayanımları } 250 \\
\text { kPa, kılcal su emme katsayıları } \leq 0.4 \mathrm{~kg} / \mathrm{m}^{2} \text { dak ve ısıl iletkenlik katsayıları } 0.065 \\
\text { W/mK dir. Köpük sıva numunelerin birim maliyetleri geleneksel ısı yalıtım } \\
\text { malzemelerinden } 1.5-3.5 \text { kat daha düşüktür. Sonuç olarak bu çalışma çimento } \\
\text { esaslı köpük sıvanın büyük ölçüde geleneksel ısı yalıtım malzemelerine alternatif } \\
\text { olabileceğini ortaya koymuştur. }\end{array}$ \\
\hline
\end{tabular}

\section{PHYSICAL, MECHANICAL AND THERMAL PROPERTIES OF CEMENT-BASED} FOAM PLASTER

Keywords
Cement Based Foam Plaster,
Thermal Insulation,
Equivalent Thickness,
Economical.

Economical.

\begin{abstract}
EPS and XPS thermal insulation boards are still widely used in building insulation in Turkey. However, the implementation of these materials has not allowed in recent years due to low fire resistance in high-rise buildings. It is possible to use materials of Class A fire resistance such as glass wool-stone wool sheets and thermal insulation plasters in such buildings. However, the significant problems encountered in glass wool - rock wool sheets are high water absorption and high unit costs. Many different brands and types of product which is defined as thermal insulation plaster are present in Turkey. However, it is a known fact that most of these products are problematic especially in terms of thermal conductivity. The aim of this study is to develop a new product with high performance, economical and easy application. Portland cement and lime as binder and, expanded perlite, coated perlite, sphere glass and diatomite as lightweight aggregate were used as binders in foam plaster mixtures. The density of the foam is $85 \mathrm{~g} / \mathrm{L}$. The water/binder ratio (0.5) was kept constant in all mixtures. Fresh and dry densities, compressive and flexural strengths, capillary water absorption and thermal conductivity tests were carried out on the specimens. Foam plaster specimens have a dry density of 250 $\mathrm{kg} / \mathrm{m} 3$, a compressive strength of $250 \mathrm{kPa}$ at 28 days, a capillary water absorption of $0.4 \mathrm{~kg} / \mathrm{m} 2$ and a thermal conductivity of $0.065 \mathrm{~W} / \mathrm{mK}$. The unit costs of foam
\end{abstract}

\footnotetext{
*ilgili yazar / Corresponding author: metindavraz@isparta.edu.tr, +90-246-511-2739
} 
plasters are 1.5-3.5 times lower than conventional thermal insulation materials. As a result, the study showed that cement based foam plaster can be an alternative to traditional thermal insulation materials.

\section{Alıntı / Cite}

Davraz, M., Gökçe, Y., Koru, M., Akdă̆, A.E., (2020). Çimento Esaslı Köpük Sıvanın Fiziksel, Mekanik ve Termal Özellikleri, Mühendislik Bilimleri ve Tasarım Dergisi, 8(1), 42-53.

Yazar Kimliği / Author ID (ORCID Number)

M. Davraz, 0000-0002-6069-7802

Y. Gökçe, 0000-0001-7384-7921

M. Koru, 0000-0002-6949-645X

A.E. Akdağ, 0000-0002-3699-9376

\section{Makale Süreci / Article Process}

\begin{tabular}{|l|l} 
Başvuru Tarihi / Submission Date & 18.05 .2019 \\
Revizyon Tarihi / Revision Date & 11.07 .2019 \\
Kabul Tarihi / Accepted Date & 16.07 .2019 \\
Yayım Tarihi / Published Date & 20.03 .2020 \\
\hline
\end{tabular}

\section{Giriş (Introduction)}

Yeryüzünde enerji kaynaklarının zamanla azalması, küresel ısınma, tüm ülkelerin enerji ihtiyaçlarını kontrol altına almalarını ve enerjiyi etkin kullanma yöntemleri geliștirmelerini zorunlu kılmıștır. Ülkemizde de başta sanayi ve konut sektörleri olmak üzere, enerji tüketimi her geçen yıl artmaktadır. Türkiye'de enerji tüketiminin \%33'ü konutlarda, \%39'u sanayide kullanılmaktadır. Konutlarda kullanılan enerjinin büyük bir bölümü ısıtma ve soğutma amaçlı tüketilmektedir. Enerjinin etkin kullanılması, ısı yalıtımı ile sağlanabilir (IMSAD, 2018).

Türkiye enerjide yaklaşık \%75 oranında dışa bağımııdır. Enerji ithalatı yıllık 55 milyar \$’ı bulmakta ve cari açıktaki en büyük paya sahip olmaktadır (XPS, 2019). Binaların ısıtma, soğutma ve havalandırmaya harcadığı enerji 17 milyar \$ seviyelerindedir. Almanya'da bir binayı ısıtmak ve soğutmak için yıllık enerji ihtiyacı 30-60 kwh/m² iken Türkiye'de 250-350 kWh/m²'dir. Kısacası Türkiye, daha soğuk bir iklime sahip Almanya'dan binaları ısıtmak veya soğutmak için neredeyse 10 kat daha fazla enerji tüketmektedir. Doğru bir ısı yalıtımı yapıldığında \%50 enerji verimi elde edilmesiyle yaklaşık 8.5 milyar \$ enerji tasarrufu yapılabilir (Yaman vd, 2015).

Avrupa standartlarında, ısı iletkenlik katsayısı ( $\lambda$ ) $0.065 \mathrm{~W} / \mathrm{mK}$ 'nin altında olan malzemeler $1 S ı$ yalıtım malzemeleri, üstünde olanlar ise yapı malzemeleri olarak tanımlanır. Bir malzemenin ısı iletkenlik katsayısı $(\lambda)$ ne kadar küçükse, yalıtımı o kadar iyi demektir. Ancak bu değer tek başına bir şey ifade etmez. Isı iletkenlik katsayısı ( $\lambda$ ) ile malzemenin kalınlığı beraber değerlendirildiğinde, o malzemenin yalıtım özelliği ile ilgili bir sonuca ulaşabilir. Bir malzemenin ısıl iletkenlik değeri düşük olsa bile, yeterli kalınlığa ulaşılamıyorsa bu malzemeyle ısı yalıtımı yapılamaz (Ünal, 2019).

Isı yalıtım malzemesi seçiminde bir diğer belirleyici özellik de malzemesinin yangın sınıfıdır. Temmuz 2015 tarihinde yayınlanan 29411 sayılı "Binaların Yangından Korunması Hakkında Yönetmelik"e göre yüksekliği 28.5 m'den fazla olan binaların dış cephelerinin en az zor yanıcı (A1, A2), diğer binalarında en az zor alevlenici (B1) malzemeden olması gereklidir (Yangın yönetmeliği, 2007). Ülkemizde genleştirilmiş polistren (EPS) ve ekstrude polistren (XPS) en geniş pazar hacmine sahip yalıtım malzemeleri iken, son yıllarda yangın yönetmeliğinin getirdiği değişiklikler, talebi sıkıştırılmış camyünü ve taş yünü lehine değiștirmeye başlamıştır. Kalsiyum silikat esaslı yalıtım plakaları da son birkaç yıldır ısı yalıtım pazarında yer almaya başlamıştır.

Çevre ve Şehircilik Bakanlığı'nca yayınlanan “Isı Yalıtım Yol Yardım Haritası” belgesinde ısı yalıtım sıvaları ile yalıtım yapılamayacağı belirtilmiştir. Öncelikle bu ifade TS EN 998-1 standardını göz ardı etmektedir. Ancak ıSı sıvalarının yalıtım malzemesi olarak adlandırılabilmesinin en temel koşulu da $\lambda_{10} \leq 0.065 \mathrm{~W} / \mathrm{mK}$ temel değerini sağlamasıdır (Çevre ve Şehircilik Bakanlığı). Ülkemizde "ısı yalıtım sıvaları" ısı yalıtım pazarında önemli bir yer tutmakta ve Türkiye'de 50'den fazla üretici firma olduğu tahmin edilmektedir. Yaygın üretim, tüketim ve ihracat rakamlarına rağmen, ülkemizde, ısı yalıtım sıvaları konusunda yapılmış bilimsel çalışma sayısı ise çok kısıtlıdır.

Davraz vd. (2011), hafif agregalı köpük sıva konusunda bir araştırma yürütmüştür. Çalışmada 3 farklı pomza ve genleștirilmiş perlit hafif agrega olarak kullanılmıştır. Köpük sıva numunelerinde kuru yoğunluk $338-487 \mathrm{~kg} / \mathrm{m}^{3}$, basınç dayanımı 0.64-2.34 MPa, eğilme dayanımı 0.070-0.11 MPa, kapiler su emme katsayısı 0.62-1.82 kg/m².dak ve ısıl iletkenlik katsayısı $0.068-0.088 \mathrm{~W} / \mathrm{mK}$ arasında değiștiği belirtilmiştir.

Bu konuda ülkemizde yürütülen az sayıdaki bilimsel çalışmadan birisi Akbulut. (2018) tarafından yapılmıştır. Çalışmada yaygın kullanılan ve tamamı TS EN 998-1 standardına göre üretilen 5 farklı firmanın ürününden ıSı yalıtım sıva numuneleri hazırlanmıştır. Hazırlanan numunelerin basınç dayanımı, eğilme dayanımı gibi mekanik özellikleri yanı sıra birim hacim kütle, kapiler su emme ve ısı iletkenlik katsayısı gibi fiziksel özellikleri incelenmiştir. Tez çalışmasında, örneklerin tamamının TS EN 998-1 standardı basınç dayanımı kriterini sağladığı (CS1 ya da CS2), kılcal su emme kriterini sadece 2 örneğin sağlayabildiği belirlenmiştir. Ayrıca, isıl iletkenlik özellikleri incelenen 5 örnekten 2'sinin TS 998-1 standardına göre T2 sinıfını $\left(\lambda_{10}>0.10 \mathrm{~W} / \mathrm{mK}\right)$ ancak 
sağlayabildiği, bununla birlikte diğer 3 örneğin T1 sınıfında $\left(\lambda_{10} \leq 0.10 \mathrm{~W} / \mathrm{mK}\right)$ yer aldığ ancak hiçbirisinin $\lambda_{10} \leq$ $0.065 \mathrm{~W} / \mathrm{mK}$ temel koșulunu sağlayamadığı belirlenmiștir. Bir kısım üretici firma ürününde ısıl iletkenlik beyan değerleri ile gerçek değerlerinin uyuşmadığı da ileri sürülmüştür.

Dylewski vd (2014) çalışmalarında bir binanın dış duvarlarında çimento sıva yerine ısı yalıtımlı bims granül veya EPS sıva kullanmanın faydalı olup olmadı̆̆ı araștırmıştır. Binada kullanılan ısı kaynağına ve bir sıva tabakası olmayan bir duvarın parametrelerine bağlı olarak bu üç çeşit sıva için (Polonya koşullarında) ekolojik ve ekonomik analizleri yapmışlardır. Bims granül ve EPS sıvalı duvarların ısı yalıtım özelliklerinde bir iyileşme sağlandığı ve bunun sonucunda enerji tüketiminde tasarruf sağlandığını belirlemişlerdir. Bu etkinin bims ve EPS sıvada ısı kaynağına bağlı olarak 2-5 yılda gerçekleştiği, çimento sıva için bu sürenin 30 yılı aştığı iddia edilmiştir.

Barbero vd. (2014) araştırmalarında, mevcut ürünleri teknik ve ekonomik özelliklere göre karşılaştırarak, Avrupa pazarındaki ısı yalıtım sıvalarının genel bir analizini yapmışlardır. Araştırmanın temel amacı, ısı yalıtım sıvası alanındaki araştırmaları yenilikçi uygulamaya doğru yönlendirmek, gerçek pazar ve son kullanıcıların taleplerini karşılayabilecek yeni sıvalar oluşturmak olarak belirtilmiştir. Avrupa standartlarına göre tanımlanan üç ana faktörün, karışımın kuru hacim kütlesi, sertleşmiş sıvanın kuru yoğunluğu ve ısıl iletkenlik olarak açıklanmıştır.

Zach vd. (2013) çalışmalarında, silika bazlı ultra hafif ısı yalıtım sıvalarının geliştirilmesine yönelik araştırma sonuçları açıklamıștır. Geliştirilen malzemelerin, yüksek açık gözeneklilik ve düşük birim hacim ağırlık nedeniyle, yapılarda ısı yalıtımı alanında önemli bir kullanım potansiyeline sahip olduğu ifade edilmiştir. Uygulamada bu malzemelerin temel gereklilikleri, kuru haldeki iletkenlik $\lambda_{10 \text {,kuru }} \leq 0.08 \mathrm{~W} / \mathrm{mK}$, minimum basınç dayanımı $\mathrm{f}_{\mathrm{c}} \geq 0.5$ $\mathrm{N} / \mathrm{mm} 2$ olarak açıklanmıştır.

Türkiye'de "ısı yalıtım sıvası” adı altında çok farklı marka ve türde ürün mevcuttur. Ancak bu ürünlerin büyük bölümünün özellikle ısı iletkenlik değeri açısından sorunlu olduğu da bilinmektedir. Bu çalışmada, yüksek performanslı, uzun servis ömürlü, ekonomik, kolay uygulanabilen ve uygulamada dübele gereksinim bırakmayan farklı bir yalıtım sıvasının geliştirilmesi amaçlanmış ve bu doğrultuda yürütülen deneysel çalışmaların bulguları sunulmuştur.

\section{Materyal ve Yöntem (Material and Method)}

Bağlayıcı madde olarak CEM 42.5 R sınıfı Portland çimentosu, karışıma aderans kazandırmak için sönmüş toz kireç, köpük üretiminde sentetik köpük ajanı ve tüm karışım gruplarında $10 \mathrm{~mm}$ uzunluğunda polipropilen elyaf kullanılmıştır. Ayrıca genleștirilmiş perlit (-2 mm), kaplı perlit, cam küre (2-1 mm, stikloporas) ya da mikronize diyatomit, kontrol hariç tüm karışımlara ilave edilmiştir. Diyatomit, Denizli ili Sarayköy ilçesi civarındaki diyatomit ocaklarından temin edilmiştir. Kaplı perlit, genleştirilmiş perlite sodyum silikat emdirilip ısıl işleme maruz bırakılarak laboratuvarda üretilmiştir. Karışım suyu olarak yerleşke şebeke suyu kullanılmıştır.

Araştırmada, 1 adedi hafif agregasız (kontrol) ve 4 farklı türde hafif agreganın 2 farklı oranda kullanıldığı toplam 9 adet çimento esaslı köpük sıva karıșımı hazırlanmıştır. Hacim esasına dayalı karıșım hesaplarında, bağlayıcı maddelerin özkütleleri $\left(\rho_{\mathrm{r}}\right)$, hafif agregaların etüv kurusu ( $\left.\rho_{\mathrm{rd}}\right)$ ya da görünür tane yoğunlukları $\left(\rho_{\mathrm{a}}\right)$ ve köpük litre ağırlığı $\left(\rho_{f}\right)$ dikkate alınmıştır. Doğal diyatomit, nem içeriğin yüksek olması nedeniyle, \%100 kuru duruma getirildikten sonra bilyalı değirmende ögütülmüş ve $150 \mu \mathrm{m}$ altına elenmiştir.

Kaplı perlit agregası eldesinde, öncelikle genleşmiş perlit $1 \mathrm{~mm}$ kare gözlü elekte elenmiş ve elek üstü bir kapta toplanmıştır. Şebeke suyundan 1 birim ve 40 bome derecesine sahip sıvı sodyum silikattan da 1 birim olmak üzere, iki sıvı kütlece $0.1 \mathrm{~g}$ hassasiyetli elektronik terazi ile tartılıp karıștırılmıştır. Sonrasında kütlece 1 birim genleştirilmiş perlite 2 birim sıvı karışım ilave edilmiş ve 24 saat kapalı bir kapta bekletilmiştir. 24 saat sonunda sıvı emdirilmiş perlit hava dolaşımlı etüvde $200^{\circ} \mathrm{C}$ de değişmez kütleye kadar kurutulmuştur.

Sıva karışımlarına 80-90 g/L yoğunlukta köpük ilave edilmiştir. 50 litre suya 1 litre köpük ajanı ilave edilerek köpük jeneratörüne beslenmiştir. Köpük sıva harçlarında, karışıma giren bileşenler $0.1 \mathrm{~g}$ hassasiyetli elektronik terazi ile tartılmıștır. 50 lt lik bir kova içerisinde el mikseri ile önce harç kısmı karıștırılmış sonra köpük ilave edilmiş ve karıștırma işlemine 3-4 dak daha devam edilmiştir. Kıvam ve boşluklu birim hacim kütle deneyleri sonrasında, taze harç 40×40x160 mm prizma ve $\varnothing 50 \times 130 \mathrm{~mm}$ silindir kalıplara dökülmüştür. Döküm ișleminden 1 gün sonra kalıplar polietilen örtüler içerisine alınmış, $20 \pm 3{ }^{\circ} \mathrm{C}$ 'de 3 gün süreyle kalıpta bekletilmiştir. Kalıptan çıkarılan numuneler $20 \pm 3{ }^{\circ} \mathrm{C}$ ve $\% 95$ bağıl nem koşullarında 28.güne kadar iklim kabininde kürlenmiștir.

Çimento fiziksel ve kimyasal özellikleri üretici firma aylık üretim raporundan alınmıştır (Göltaş, 2019). Kireç ve diyatomitin özkütlesi ( $\rho_{r}$ ) ile kaplı perlit ve cam kürenin görünür tane yoğunluğu ( $\rho_{r}$ ), Süleyman Demirel 
Üniversitesi Doğal ve Endüstriyel AUM'nde (SDÜ DEYMAM) gaz piknometresi (Micrometrics-AccuPyc 1340) ile belirlenmiştir. Genleşmiş perlit tane yoğunluğu ve su emme oranı ile cam küre, kaplı perlit ve diyatomitin su emme oranları TS EN 1097-6 standardına göre belirlenmiştir. Taze harcın birim hacim kütlesinin tayini deneyinde harç, ölçü kabına boşluk kalmayacak biçimde doldurulmuş ve yüzeyi düzeltilmiştir. Harçla doldurulmuş ölçü kabı toplam kütlesi $1 \mathrm{~g}$ hassasiyetli terazi ile tartılmıştır. Taze harcın boşluklu birim hacim kütlesi $\left(\rho_{\mathrm{m}}\right)$ Eşitlik 1'de verilen bağıntı yardımıyla hesaplanmıştır (TS EN 1015-6).

$$
\rho_{\mathrm{m}}=\frac{\mathrm{M}_{2}-\mathrm{M}_{1}}{\mathrm{~V}_{\mathrm{v}}}
$$

Burada; $\rho_{m}$, taze harcın boșluklu birim hacim kütlesi, kg/m³; $\mathrm{M}_{1}$, ölçü kabının kütlesi, g; $\mathrm{M}_{2}$, taze harç dolu ölçü kabının kütlesi, g; $V_{v}$, ölçü kabının hacmi, cm$^{3}$ dir. 28 günlük kür süresi sonrasında köpük sıva harcı numunelerine kuru birim hacim kütle, kılcal su emme, eğilme-basınç dayanımı ve ısıl iletkenlik deneyleri uygulanmıştır. Harç numunelerinin kuru birim hacim kütlesini belirlemek için, TS EN 1015-10 standardına uygun olarak, numuneler sabit kütleye ulaşıncaya kadar hava dolaşımlı etüvde $70^{\circ} \mathrm{C} \pm 3^{\circ} \mathrm{C}$ 'de kurutulmuştur. Sonrasında $0.01 \mathrm{~g}$ duyarlığa sahip elektronik terazi ile her bir numunenin kütlesi ölçülmüş ve kaydedilmiştir. Daha sonra her bir numunenin eni (w), boyu (L) ve yüksekliği (h) $0.01 \mathrm{~mm}$ hassasiyetli elektronik kumpasla ölçülmüş ve hacmi hesaplanmıştır. Numune kuru birim hacim kütlesi Eşitlik 2'de verilen bağıntı yardımıyla hesaplanmıștır.

$$
D_{\text {kuru }}=\frac{M_{s, \text { kuru }}}{V_{S}}
$$

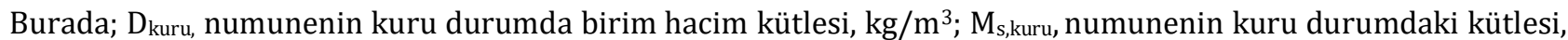
g; V, numunenin hacmi, $\mathrm{cm}^{3}$ dir. 6 adet prizma numunesi hesaplanan yoğunluğunun aritmetik ortalaması, numunenin kuru birim hacim kütlesi olarak alınmıştır. Kuru durumdaki 40x40x160 mm boyutlarında 3'er adet prizma numune üzerinde TS EN 1015-18 standardına uygun olarak kapiler su emme deneyleri yürütülmüştür. Su içine yerleştirilen numunelerin kütleleri 10. ve 90. dak'nın sonunda ölçülmüştür. Numunelerin kılcal su emme katsayıları Eşitlik 3'de verilen bağıntı yardımıyla hesaplanmıştır.

$$
c=0.1 x\left(M_{2}-M_{1}\right)
$$

Burada; c, kapiler su emme katsayısı, $\mathrm{kg} /\left(\mathrm{m}^{2}\right.$. dak $\left.{ }^{0.5}\right) ; \mathrm{M}_{1}$, numunenin 10 dak sonra tartılan kütlesi, g; $\mathrm{M}_{2}$, numunenin 90 dak sonra tartılan kütlesi, g'dır. Her bir sıva grubundan 3 adet numunenin kapiler su emme katsayısının aritmetik ortalaması, harç grubunun kapiler su emme katsayısı olarak kaydedilmiştir.

Köpük sıva numuneleri üzerinde, eğilmede çekme (3 noktadan yükleme) ve basınç dayanımı deneyleri TS EN 1015-11 standardına uygun olarak yürütülmüştür. 3 adet 40×40×160 mm boyutlarında prizma numuneler kullanılmıştır. Mesnetler arası mesafe, $100 \mathrm{~mm}$ dir. Numune grubunun eğilmede çekme dayanımı, 3 adet numunenin aritmetik ortalamasıdır. Eğilme yükü numunelerin üst yüzeyinin orta noktasından uygulanmış ve yüklemeye numune kırılıncaya kadar devam edilmiştir. Yükleme hızı $30 \mathrm{~N} / \mathrm{s}$ olarak seçilmiştir. Numunelerin eğilmede çekme dayanımları Eșitlik 4'de verilen bağıntı kullanılarak hesaplanmıştır.

$$
f_{c f}=1.5 \times \frac{F \times L}{b \times d^{2}}
$$

Burada; fcf, eğilmede çekme dayanımı, MPa; F, en büyük yük, N; L, mesnet silindirleri arasındaki açıklık, mm; b ve d, numunenin en kesit boyları, mm'dır. Aynı numune gruplarından 40x40x160 mm boyutlarında 6 adet prizma numune üzerinde basınç dayanımı deneyi yürütülmüştür. Bu deney için eğilmede çekme-basınç dayanımı deneyinde kullanılan test cihazının basınç dayanımı test bölümü kullanılmıştır. Prizma kalıptan çıkan kenarı, pres başlıkları veya yükleme başlıklarının en yakın kenarından $16 \mathrm{~mm} \pm 0,1 \mathrm{~mm}$ uzaklıkta olacak şekilde yerleştirilmiştir. Yükleme hızı TS EN 1015-11 standardına uygun olarak 250 N/s olarak seçilmiştir. Köpük sıva numunelerinin 28 günlük basınç dayanımları Eşitlik 5'de verilen bağıntı yardımıyla hesaplanmıştır.

$$
f_{c}=\frac{F}{A_{c}}
$$

Burada; f, basınç dayanımı, MPa; F, kırılma yükü, N; $A_{c}$, numunenin yük doğrultusundaki kesit alanı, mm²'dır. 55 mm çapında 130 mm yüksekliğinde silindirik köpük sıva numunelerinden 3'er adet 25 mm yüksekliğinde parçalar kesilmiş ve yüzeyleri zımpara ile düzeltilmiştir. Bu numune bölümleri üzerinde TS EN 12667 standardına uygun olarak ısıl iletkenlik katsayısı ölçümleri, SDÜ DEYMAM’nde ısı akısı ölçme yöntemi prensibine göre ölçüm yapan Lasercomp Fox50 ısıl iletkenlik test cihazı ile gerçekleştirilmiştir. Isıl iletkenlik ölçümleri öncesinde numuneler hava dolașımlı etüvde $70^{\circ} \mathrm{C}$ 'de değişmez kütleye kadar kurutulmuştur. Test cihazının sıcak ve soğuk plakaları arasında sıcaklık farkı (dT) $10 \mathrm{~K}$ olarak ayarlanmıştır. 
Köpük sıva numunelerinde bağlayıcı madde olarak kullanılan CEM I 42.5 R sınıfı Portland çim entosu kullanılmıştır. Çimentonun özellikleri Tablo 1'de verilmiştir.

Tablo 1. Cimento özellikleri (The properties of cement) (Göltaș, 2019)

\begin{tabular}{|c|c|c|c|}
\hline \multicolumn{4}{|c|}{ Çimento Kimyasal ve Fiziksel Özellikleri } \\
\hline $\begin{array}{c}\text { Bileşenler } \\
\text { (\%) }\end{array}$ & $\%$ & $\begin{array}{c}\text { Fiziksel ve Mekanik } \\
\text { Özellikler }\end{array}$ & \\
\hline $\mathrm{SiO}_{2}$ & 20.52 & Hacimsel Genleșme (mm) & 1 \\
\hline $\mathrm{Al}_{2} \mathrm{O}_{3}$ & 4.00 & İncelik $(90 \mu)$ & 0.10 \\
\hline $\mathrm{Fe}_{2} \mathrm{O}_{3}$ & 3.45 & İncelik $(200 \mu)$ & 1.10 \\
\hline $\mathrm{CaO}$ & 64.28 & Özgül Yüzey Alanı $\left(\mathrm{cm}^{2} / \mathrm{g}\right)$ & 4010 \\
\hline $\mathrm{MgO}$ & 1.63 & Priz Başlangıcı (dak) & 160 \\
\hline $\mathrm{SO}_{3}$ & 2.53 & Priz Sonu (dak) & 210 \\
\hline $\mathrm{Na}_{2} \mathrm{O}+\mathrm{K}_{2} \mathrm{O}$ & 0.71 & Özgül Ağırlık (g/ $\left./ \mathrm{cm}^{3}\right)$ & 3.14 \\
\hline $\mathrm{CaO}$ (Serbest) & 1.81 & $\begin{array}{c}\text { Basınç Dayanımı (2 günlük, } \\
\text { MPa) }\end{array}$ & 24.2 \\
\hline K.K. & 2.72 & $\begin{array}{c}\text { Basınç Dayanımı (28 günlük, } \\
\text { MPa) }\end{array}$ & 51.5 \\
\hline Diğer & $\%$ & Klinker & $\%$ \\
\hline $\mathrm{Cl}^{-}(\%)$ & 0.005 & $\mathrm{C}_{3} \mathrm{~S}$ & 53.40 \\
\hline C.K.K. & 0.58 & $\mathrm{C}_{2} \mathrm{~S}$ & 16.64 \\
\hline A.E. & 0.61 & $\mathrm{C}_{3} \mathrm{~A}$ & 5.48 \\
\hline & & $\mathrm{C}_{4} \mathrm{AF}$ & 10.4 \\
\hline
\end{tabular}

\section{Deneysel Sonuçlar (Experimental Results)}

Köpük harç bileşenlerinde hafif agrega olarak kullanılan genleşmiș perlit ve diyatomitin kimyasal özellikleri Tablo 2'de verilmiștir. Hafif agregaların oksit bileșenleri GÖLTAȘ A.Ş. Kalite Kontrol Laboratuvarı'nda X-Ișını Floresans spektrometresi (XRF) ile yapılmıştır.

Tablo 2. Genleștirilmiș perlit ve diyatomitin kimyasal özellikleri (The chemical properties of expanded perlite and diatomite)

\begin{tabular}{|c|c|c|c|c|c|c|c|c|c|}
\hline $\begin{array}{c}\text { Malzeme } \\
\text { Adı }\end{array}$ & $\begin{array}{c}\mathrm{Si}_{2} \\
(\%)\end{array}$ & $\begin{array}{c}\mathrm{Al}_{2} \mathrm{O}_{3} \\
(\%)\end{array}$ & $\begin{array}{c}\mathrm{Fe}_{2} \mathrm{O}_{3} \\
(\%)\end{array}$ & $\begin{array}{c}\mathrm{Ca} 0 \\
(\%)\end{array}$ & $\begin{array}{c}\mathrm{Mg} 0 \\
(\%)\end{array}$ & $\begin{array}{c}\mathrm{Na}_{2} \mathrm{O} \\
(\%)\end{array}$ & $\begin{array}{c}\mathrm{K}_{2} \mathrm{O} \\
(\%)\end{array}$ & $\begin{array}{c}\mathrm{SO}_{3} \\
(\%)\end{array}$ & $\begin{array}{c}\mathrm{K} . \\
\mathrm{Kayb} 1 \\
(\%)\end{array}$ \\
\hline $\begin{array}{c}\text { Genleștirimis } \\
\text { Perlit }\end{array}$ & 75.09 & 13.22 & 0.61 & 0.61 & 0.23 & 3.13 & 4.81 & 0.003 & 1.20 \\
\hline Diyatomit & 79.01 & 2.77 & 2.14 & 3.07 & 2.88 & 0.19 & 0.68 & 0.78 & 7.73 \\
\hline
\end{tabular}

SDU DEYMAM’nde gaz piknometresi ile; diyatomit özkütlesi $2.27 \mathrm{~g} / \mathrm{cm}^{3}$, kirecin özkütlesi $2.47 \mathrm{~g} / \mathrm{cm}^{3}$, genleşmiș perlit-kaplı perlit ve hafif cam kürenin görünür tane yoğunlukları ise sırasıyla $0.883,0.934$ ve $0.997 \mathrm{~g} / \mathrm{cm}^{3} \mathrm{olarak}$ ölçülmüştür. TS EN 1097-6 standardına göre genleşmiş perlitin, kaplı perlitin ve hafif cam kürenin 24 saatlik kütlece su emme oranları sırasıyla \% 125, \% 67 ve \% 18 olarak belirlenmiștir.

Tüm karışım tasarımlarında Portland çimentosuna ilave olarak, sıva harcına aderans kazandırma amacıyla çimento kütlesinin \% 40'ı oranında sönmüș (toz) kireç kullanılmıştır. Kontrol karışımı (K) hariç her grupta toplam bağlayıcı miktarı (çimento+kireç) $25 \mathrm{~kg} / \mathrm{m}^{3}$ ve $50 \mathrm{~kg} / \mathrm{m}^{3}$ azaltılmış, karışımlara azaltılan miktarlarda hafif agrega türünden birisi ilave edilmiştir. Tüm harç karışımlarına çimento kütlesini \%0.5'i oranında polipropilen elyaf (15 $\mathrm{mm}$ ) ilave edilmiş, s/b oranları (0.5) sabit tutulmuştur. Karışımların teorik kuru birim hacim kütleleri $250 \mathrm{~kg} / \mathrm{m}^{3}$ olarak belirlenmiştir. Köpük sıva harçlarının karışım tasarımları Tablo 3'de verilmiştir.

28 günlük kür süresini tamamlayan bir gruptan 6 adet köpük sıva prizma numunesi, TS EN 1015-10 standardına uygun olarak $70^{\circ} \mathrm{C}$ de değişmez kütleye kadar hava dolaşımlı etüvde kurutulmuştur. Kurutulan numuneleri boyutları $0.01 \mathrm{~mm}$ hassasiyetle elektronik kumpasla ölçülmüş ve $0.01 \mathrm{~g}$ hassasiyetli elektronik terazide kütleleri tartılmıştır. Daha sonra numunelerin kuru birim hacim kütleleri hesaplanmış ve sonuçlar Şekil 1'de verilmiştir 
Tablo 3. Çimento esaslı köpük sıva numunelerinin karışım tasarımları (The mix designs of foam plaster specimens based

\begin{tabular}{|c|c|c|c|c|c|c|c|c|c|c|}
\hline \multicolumn{11}{|c|}{ cement) } \\
\hline $\begin{array}{l}\stackrel{ْ}{Z} \\
\stackrel{\Xi}{E} \\
\stackrel{E}{E}\end{array}$ & 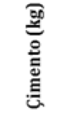 & 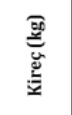 & 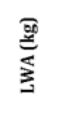 & 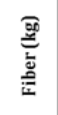 & $\begin{array}{l}\text { 말 } \\
\stackrel{\vec{D}}{\vec{n}}\end{array}$ & 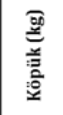 & ลิ & $\stackrel{*}{*}$ & 蛋 & 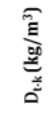 \\
\hline K & 178.0 & 71.2 & 0 & 1.25 & 124.6 & 67.0 & 0.5 & 0.50 & 442 & 252 \\
\hline GP1 & 160.0 & 64.0 & 25.0 & 1.12 & 112.0 & \begin{tabular}{|l|}
58.2 \\
\end{tabular} & 0.5 & 0.45 & 420 & 251 \\
\hline GP2 & 143.0 & 57.2 & 50.0 & 1.00 & 100.1 & \begin{tabular}{|l|}
49.3 \\
\end{tabular} & 0.5 & 0.40 & 401 & 252 \\
\hline CK1 & 160.0 & 64.0 & 25.0 & 1.12 & 112.0 & 61.7 & 0.5 & 0.45 & 424 & 251 \\
\hline CK2 & 143.0 & 57.2 & 50.0 & 1.00 & 100.1 & \begin{tabular}{|l|}
49.3 \\
\end{tabular} & 0.5 & 0.40 & 408 & 252 \\
\hline KP1 & 160.0 & 64.0 & 25.0 & 1.12 & 112.0 & $\mid 61.7$ & 0.5 & 0.45 & 425 & 251 \\
\hline KP2 & 143.0 & 57.2 & 50.0 & 1.00 & 100.1 & \begin{tabular}{|l|}
49.3 \\
\end{tabular} & 0.5 & 0.40 & 410 & 252 \\
\hline DY1 & 160.0 & 64.0 & 25.0 & 1.12 & 112.0 & 68.0 & 0.5 & 0.45 & 430 & 251 \\
\hline DY2 & 143.0 & 57.2 & 50.0 & 1.00 & 100.1 & \begin{tabular}{|l|}
48.8 \\
\end{tabular} & 0.5 & 0.40 & 420 & 252 \\
\hline$L W A$ & $\therefore \mathrm{Ha}$ & grega & & $D_{t: z z}$ & : & $\begin{array}{l}\text { rik taze } \\
\text { ğunluk }\end{array}$ & $D_{t ; k}$ & : & $\begin{array}{c}\text { Teori } \\
\text { yoğ }\end{array}$ & \\
\hline$K$ & : Ko & rol harct & & $G P$ & : & $\begin{array}{l}\text { alesmis } \\
\text { erlitli } \\
\text { ük siva }\end{array}$ & $K P$ & & $\begin{array}{c}\text { Kaph } \\
\text { köpü }\end{array}$ & $\begin{array}{l}\text { erlitli } \\
\text { siva }\end{array}$ \\
\hline$C K$ & Co & $\begin{array}{l}\text { agregal } \\
\text { siva }\end{array}$ & köpük & $D Y$ & $:$ & $\begin{array}{l}\text { atomitli } \\
\text { ük siva }\end{array}$ & & & & \\
\hline 1 & : & itlece \% & LWA't & cöpük $s$ & & 2 & & & $\begin{array}{l}L W A^{\prime} \\
v a\end{array}$ & \\
\hline
\end{tabular}

Çalışmada $250 \mathrm{~kg} / \mathrm{m}^{3}$ ve daha düşük kuru birim hacim kütle hedefine, 9 farklı köpük sıva karışımı tasarımından ancak 4 adedi (K, GP2, KP2 ve DY1) ile ulaşılabilmiştir. Bununla birlikte GP1'in kuru birim hacim kütlesi de hedeflenen değere oldukça yakındır $\left(256 \mathrm{~kg} / \mathrm{m}^{3}\right)$.

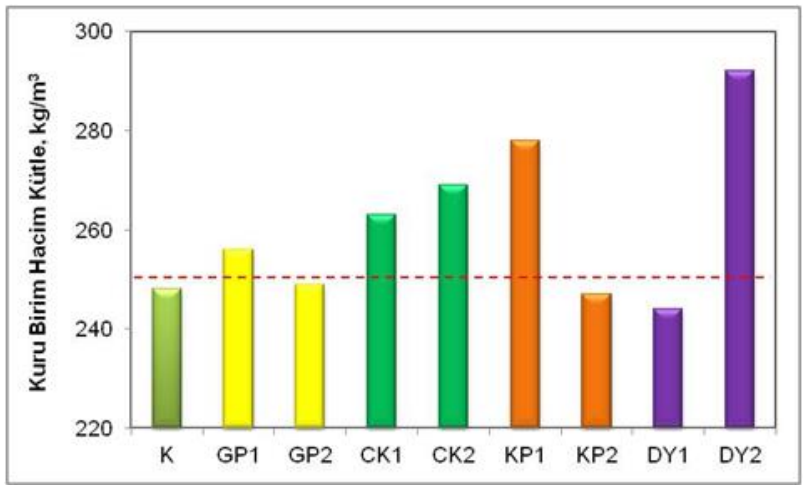

Şekil 1. Köpük sıva numunelerinin kuru birim hacim kütlelerinin karşılaştırılması (The unit volume per masses of foam plaster specimens)

Köpük sıva numunelerin kılcal (kapiler) su emme değerleri TS EN 1015-18 standardına uygun olarak belirlenmiş ve bulgular Şekil 2'de verilmiştir.

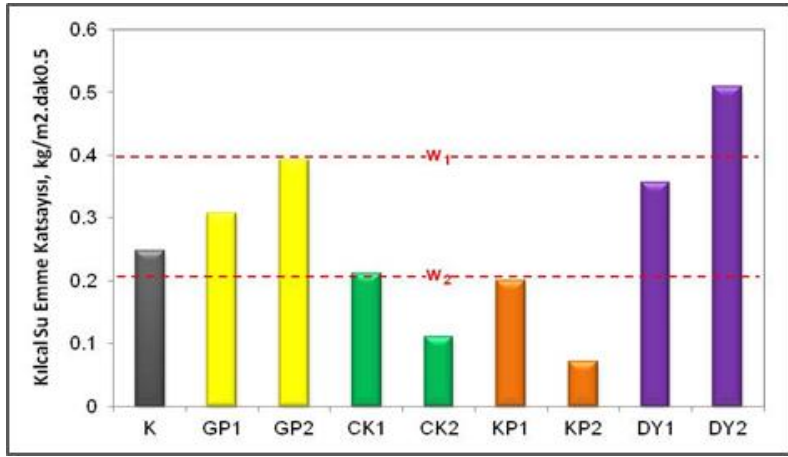

Şekil 2. Köpük sıva numuneleri kılcal su emme katsayılarının karşılaștırılması (The capillary water apsorption of foam plaster specimens)

TS EN 998-1 standardına göre, CK2, KP1 ve KP2 numuneleri W2 sınıfına, K, CK1, GP1, GP2 ve DY1 numuneleri W 1 sınıfına girmektedir (Şekil 2). Bununla birlikte, köpük sıva harcı bileşiminde herhangi bir su itici katkı maddesi kullanılmadığı dikkate alındığında, köpük sıva numunelerinin kılcal su emme katsayılarının nispeten düşük 
olduğunu söylemek mümkündür. Bu durum köpük sıva içerisinde ortalama çapı $100 \mu$ m civarındaki hava küreciklerinin kapiler kanalcıkları tıkamasıyla ilişkilendirilmiştir.

Isı yalıtım sıvalarında eğilme dayanımı önemli bir mekanik özelliktir. 28 günlük kür süresini tamamlamış ve değișmez kütleye kadar kurutulmuş her bir köpük sıva grubundan 3 adet prizma üzerinde eğilme dayanımı deneyleri yürütülmüş ve bulgular Şekil 3'de verilmiştir.

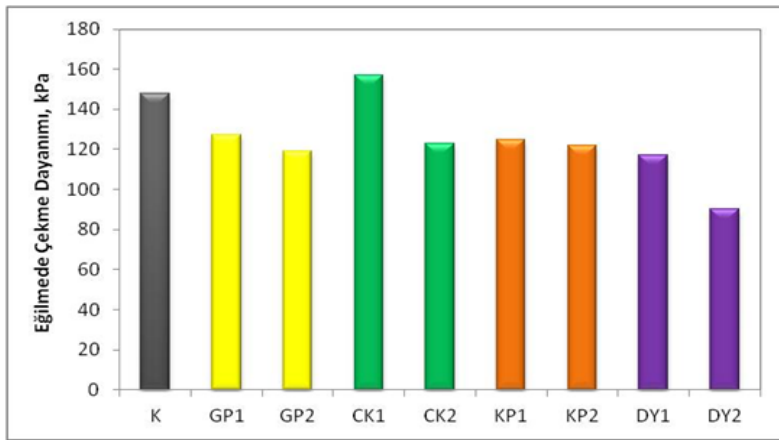

Şekil 3. Köpük sıva numuneleri eğilme dayanımlarının karşılaștırılması (The bending strengths of foam plaster specimens)

En yüksek eğilme dayanımı değerini CK1 (157 kPa) sergilemiștir. Kontrol numunesi dayanımı da CK1 numunesine (148 kPa) yakın bir eğilme dayanımına sahiptir. CK1 numunesinin, nispeten daha yüksek eğilme dayanımı sergilemesi, karışıma ilave edilen cam kürecik ile ilişkilendirilmiştir. Ancak cam küre içeriği arttıkça eğilme dayanımı \%22 civarında azalmıştır. Bu durum, köpük sıvada eğilme dayanımının kullanılan agrega türünden daha çok matrisi oluşturan köpük harcının sorumlu olduğunu, kullanılan agrega tane boyutu azaldıkça eğilme dayanımının düşebileceğini göstermektedir. İlave olarak, en düşük eğilme dayanımı değerlerinin DY numunelerinde sergilenmiş olması, doğal diyatomitin yüksek miktarda kil içermesiyle ilişkilendirilmiştir.

Basınç dayanımı deneyleri 6 adet tam prizma üzerinde yürütülmüştür. 28 günlük kür süresini tamamlamış ve değișmez kütleye kadar kurutulmuş prizma numunelerinde, 6 adet prizma numunesinin aritmetik ortalaması basınç dayanımı olarak alınmıştır. Kütlece \%10 oranında cam küre kullanımı (CK1) köpük sıva numunesinin basınç dayanımını \%12 oranında artırmıştır. \%10 civarında kaplı perlit kullanımında (KP1) ise kontrol numunesine göre basınç dayanımı yaklaşık aynıdır. \%10 oranında genleşmiş perlit kullanımında (GP1) dayanım \%14, \%20 oranında (GP2) ise \%25 civarında azalmıştır. Diyatomit de ise \%10 kullanımda (DY1) \%24, \%20 kullanımda (DY2) ise \%40 civarında dayanım kaybı gözlenmiştir (Şekil 4). Hiçbir numunede hedeflenen $\geq 500$ kPa basınç dayanım değerine ulaşılamamıştır, TS EN 998-1 standardında en düşük dayanım sınıfı olarak belirtilen CS1 (0.4-2.5 MPa) koşulu sağlanamamıştır. Bu durum numunelerin nispeten düşük birim hacim kütleleri ile ilişkilendirilmiştir.

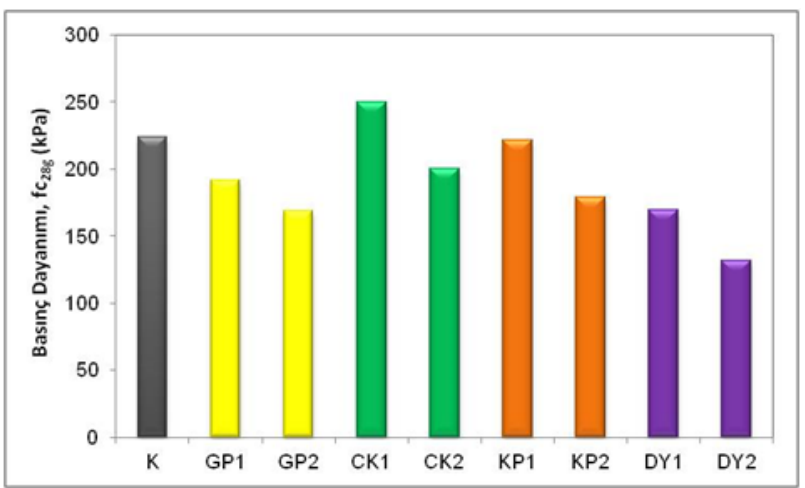

Şekil 4. Köpük sıva numuneleri basınç dayanımlarının karşılaştırılması (The compressive strengths of foam plaster specimens)

Köpük sıva numunelerinin, TS EN 12667 standardına uygun olarak Lasercomp Fox 50 cihazı ile ölçülen ısıl iletkenlik katsayıları $\left(\lambda_{10}\right)$ Şekil 5'de verilmiştir. Köpük sıva numunelerinin ısıl iletkenlik sınırı, ısı yalıtım malzemeleri için kabul edilen $\left(\lambda_{10 \text {-kuru }}\right) \leq 0.065 \mathrm{~W} / \mathrm{mK}$ olarak belirlenmiștir. Bu koşulu 4 adet köpük sıva numunesi sağlarken (K, GP1, GP2 ve DY1), diğerlerinin ısıl iletkenlik katsayıları sınır değerin üstündedir. Bununla beraber TS EN 998-1 standardında (T1 sınıfı) ısı yalıtım sıvaları için belirlenen $0.10 \mathrm{~W} / \mathrm{mK}$ üst sınırını tüm numuneler sağlamıştır. 


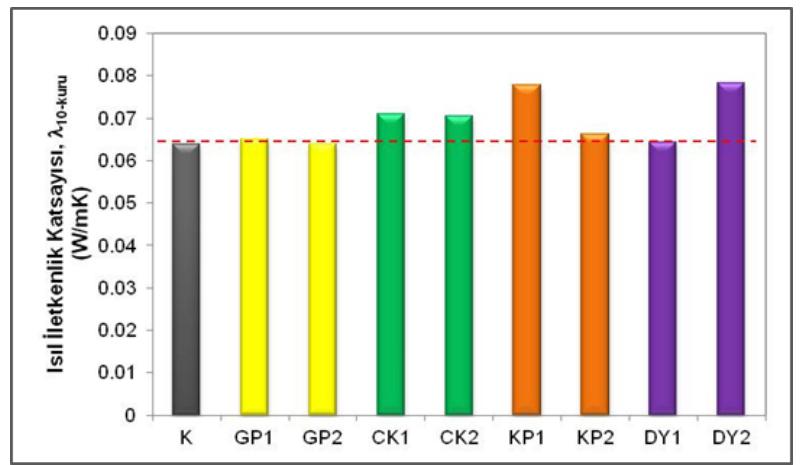

Şekil 5. Köpük sıva numunelerinin ısıl iletkenlik katsayılarının karşılaştırılması (The thermal conductivity coefficients of foam plaster specimens)

Ölçüm bulguları, köpük sıva numunelerinin ısll iletkenlik katsayılarının ( $\left.\lambda_{10-k u r u}\right)$ kullanılan hafif agrega türünden daha çok kuru birim hacim kütleleri $\left(\rho_{\mathrm{m}}\right)$ ile yakından ilişkili olduğunu ortaya koymuștur. Çalıșma kapsamında üretilen köpük sıva numunelerinde, $\lambda_{10 \text {-kuru }}-\rho_{\mathrm{m}}$ ilişsisi Şekil 6' da incelenmiştir.

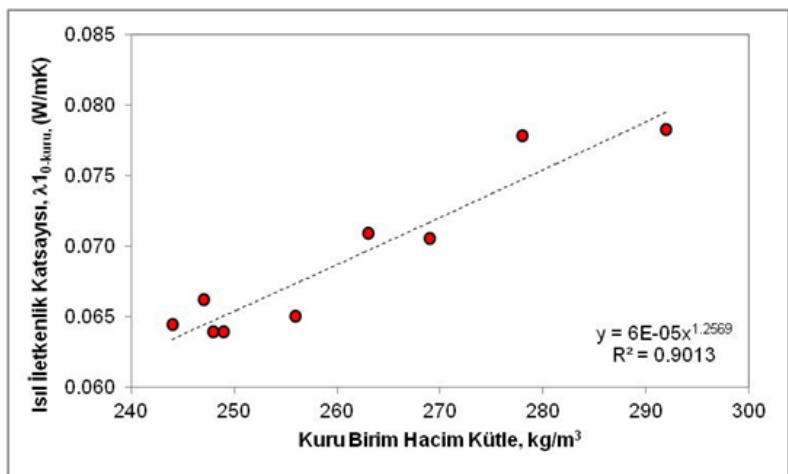

Şekil 6. Köpük sıva numunelerinde $\lambda_{10-k u r u}-\rho_{m}$ ilişkisi $\left(\lambda_{10-k u r u}-\rho_{m}\right.$ relationship in foam plaster specimens)

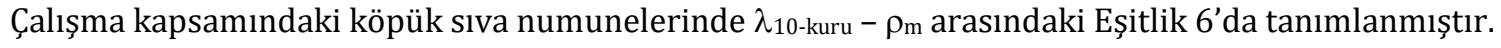

$$
\lambda_{10-k u r u}=6 \times 10^{-5} \times \rho_{m}^{1.257} \quad\left(\mathrm{R}^{2}=0.90\right)
$$

Çimento esaslı köpük sıvaların (K ya da GP1) ısı bölgelerine göre uygulama kalınlıklarının belirlenebilmesi için 19 $\mathrm{cm}$ kalınlığında, $600 \mathrm{~kg} / \mathrm{m}^{3}$ brüt yoğunlukta yatay delikli tuğla duvar dolgu elemanı olarak seçilmiștir. Tuğla duvarın tasarım isıl iletkenlik katsayısı $\left(\lambda_{\mathrm{h}}\right)$ olarak standartta (TS 825,EK E, Madde 7.1.5) belirtilen $0.33 \mathrm{~W} / \mathrm{mK}$ değeri esas alınmıștır. TS 825 standardında ısı bölgelerine göre dıș duvarlar için ısı geçiş katsayıları (UD); I. Isı bölgesi için $\leq 0.70 \mathrm{~W} / \mathrm{m}^{2} \mathrm{~K}$, II. Isı bölgesi için $\leq 0.60 \mathrm{~W} / \mathrm{m}^{2} \mathrm{~K}$, III. Isı bölgesi için $\leq 0.50 \mathrm{~W} / \mathrm{m}^{2} \mathrm{~K}$, IV. Isı bölgesi için $U_{D}$ $\leq 0.40 \mathrm{~W} / \mathrm{m}^{2} \mathrm{~K}$ dir. Yukarıda belirtilen $\mathrm{U}_{\mathrm{D}}$ katsayısı dikkate alınarak, tüm ısı bölgeleri için köpük sıva uygulama kalınlıkları hesaplanmış, (I. Isı bölgesi için) örnek çözüm Tablo 4'de verilmiştir. Yeni inşa edilen bir bina için köpük sıvanın iç ve dış duvarda uygulanması durumunda en az kalınlıklar, I. Isı bölgesi için $2.5 \mathrm{~cm}+2.0 \mathrm{~cm}$, II. ISı bölgesinde $3.0 \mathrm{~cm}+3.0 \mathrm{~cm}$, III. ISı bölgesinde $4.0 \mathrm{~cm}+4.0 \mathrm{~cm}$ ve IV. Isı bölgesinde ise $6.0 \mathrm{~cm}+5.5 \mathrm{~cm}$ 'dir. Kalınlık arttıkça, sıvanın duvar yüzeyine tutunması gibi güçlükler ile karşılaşılması mümkündür. Bu bakımdan köpük sıvanın ısı yalıtım malzemesi olarak kullanılabilmesi, özellikle III. ve IV. ısı bölgelerinde iç ve dış sıva olarak birlikte uygulanabilmesine bağlıdır.

4 farklı ısı bölgesi için uygulama kalınlıklarına bağlı olarak (K ve GP1 tipi) köpük sıvaların birim fiyat analizleri Tablo 5 ve Tablo 6'da verilmiştir. Analizde, Nisan 2019 yılı hammadde birim fiyatları esas alınmıştır. Hammadde maliyetleri \%25 oranında artırılarak diğer girdiler (işçilik, enerji, kar vd.) birim fiyatlara ilave edilmiştir. Sonrasında ısı bölgelerine göre minimum uygulama kalınlıklarına göre $1 \mathrm{~m}^{2}$ birim fiyatı hesaplanmıştır (Tablo 5 ve 6). Isı bölgelerine göre $\mathrm{K}$ tipi köpük sıvanın birim fiyatı $\sim 5-13 \mathrm{TL} / \mathrm{m}^{2}$, GP1 tipi köpük sıvanın ise $~ 6.5-16.5$ $\mathrm{TL} / \mathrm{m}^{2}$ aralığında değișmektedir. Geleneksel yalıtım malzemeleri ve mantolamada kullanılan diğer malzemelerin güncel birim fiyatları da Tablo 7'de verilmiştir. 
Tablo 4. I. Isı bölgesi için köpük sıva uygulama kalınlığı hesabı (The calculation of foam plaster application thickness fo climates zone I)

\begin{tabular}{|c|c|c|c|c|c|c|}
\hline \multicolumn{3}{|c|}{$\begin{array}{c}\text { Kesitteki Yapı } \\
\text { Bileșenleri }\end{array}$} & $\begin{array}{c}\text { Yapı } \\
\text { Elemanı } \\
\text { Kalınlığı, d } \\
\text { (m) }\end{array}$ & $\begin{array}{c}\text { Isıl İletkenlik } \\
\text { Hesap Deǧeri, } \\
\lambda_{\mathrm{h}}(\mathrm{W} / \mathrm{mK})\end{array}$ & $\begin{array}{c}\mathrm{d} / \lambda \\
1 / \alpha \\
\left(\mathrm{m}^{2} \mathrm{~K} / \mathrm{W}\right)\end{array}$ & $\begin{array}{c}\text { Isıl Geçirgenlik } \\
\text { Katsayısı, U } \\
\left(\mathrm{W} / \mathrm{m}^{2} \mathrm{~K}\right)\end{array}$ \\
\hline \multirow{5}{*}{ I. } & $1 / \alpha_{1}$ & 1 & - & - & 0.13 & \\
\hline & Köpük Siva & 2 & 0.025 & 0.064 & 0.391 & \\
\hline & Yatay Delikli & & 0.19 & 0.330 & 0.576 & \\
\hline & Köpük Sıva & 2 & 0.020 & 0.064 & 0.313 & \\
\hline & $1 / \alpha_{d}$ & 1 & - & - & 0.040 & \\
\hline \multicolumn{5}{|c|}{ TOPLAM } & 1.449 & 0.69 \\
\hline \multicolumn{4}{|c|}{${ }^{1}$ TS 825 Cizelge 2} & 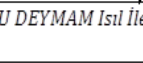 & enlik ana. & onucu \\
\hline
\end{tabular}

Tablo 5. Isı bölgelerine göre "K tipi" köpük sıva birim maliyetleri (The unit cost of "K type" foam plaster according to climate

\begin{tabular}{|c|c|c|c|}
\hline \multicolumn{4}{|c|}{ zone) } \\
\hline Hammadde & Miktar $\left(\mathrm{kg} / \mathrm{m}^{3}\right)$ & Fiyat (t) & TUTAR (t) \\
\hline Çimento & 178 & 0.18 & 32.04 \\
\hline Kireç & 71.2 & 0.12 & 8.64 \\
\hline LWA & 0 & 1.50 & 0.00 \\
\hline Elyaf & 1.12 & 6.00 & 7.50 \\
\hline Köpük Ajanı & 1.75 & 20.00 & 40.00 \\
\hline \multicolumn{3}{|c|}{$1 \mathrm{~m}^{3}$ Köpük Sıva Hammadde Maliyeti $\left(€ / \mathrm{m}^{3}\right)$} & 88.18 \\
\hline \multicolumn{3}{|c|}{ Diğer Maliyetler (İşçilik, enerji, nakliye, kar vd.) (も/m³) } & 22.05 \\
\hline \multicolumn{3}{|c|}{$1 \mathrm{~m}^{3}$ Köpük Sıva Birim Fiyatı (Tahmini) $\left(€ / \mathrm{m}^{3}\right)$} & 110.23 \\
\hline \multicolumn{3}{|c|}{ Kalınlık $4.5 \mathrm{~cm}$ (I. Bölge) $\left(€ / \mathrm{m}^{2}\right)$} & 4.96 \\
\hline \multicolumn{3}{|c|}{ Kalınlık $6 \mathrm{~cm}$ (II. Bölge) (£/m²) } & 6.61 \\
\hline \multicolumn{3}{|c|}{ Kalınlık $8 \mathrm{~cm}$ (II. Bölge) (も/m²) } & 8.82 \\
\hline \multicolumn{3}{|c|}{ Kalınlık $11.5 \mathrm{~cm}$ (IV. Bölge) (も/m²) } & 12.68 \\
\hline
\end{tabular}

Tablo 6. Isı bölgelerine göre "GP1 tipi" köpük sıva birim maliyetleri (The unit cost of "GP1 type" foam plaster according to climate zone)

\begin{tabular}{|c|c|c|c|}
\hline Hammadde & Miktar $\left(\mathrm{kg} / \mathrm{m}^{3}\right)$ & Fiyat (TL) & TUTAR (TL) \\
\hline Çimento & 160 & 0.18 & 28.80 \\
\hline Kireç & 64 & 0.12 & 7.68 \\
\hline LWA & 25 & 1.50 & 37.50 \\
\hline Elyaf & 1.12 & 6.00 & 6.72 \\
\hline Köpük Ajanı & 1.75 & 20.00 & 35.00 \\
\hline \multicolumn{3}{|c|}{$1 \mathrm{~m}^{3}$ Köpük SIva Hammadde Maliyeti $\left(\mathrm{TL} / \mathrm{m}^{3}\right)$} & 115.70 \\
\hline \multicolumn{3}{|c|}{ Diğer Maliyetler (isşçilik, enerji, nakliye, kar vd.) (TL/m³) } & 28.93 \\
\hline \multicolumn{3}{|c|}{$1 \mathrm{~m}^{3}$ Köpük Sıva Birim Fiyatı (Tahmini) (TL/m³) } & 144.63 \\
\hline \multicolumn{3}{|c|}{ Kalınlık $4.5 \mathrm{~cm}$ (I. Bölge) (TL/m²) } & 6.51 \\
\hline \multicolumn{3}{|c|}{ Kalınlık $6 \mathrm{~cm}$ (II. Bölge) (TL/m²) } & 8.68 \\
\hline \multicolumn{3}{|c|}{ Kalınlık $8 \mathrm{~cm}$ (II. Bölge) $\left(\mathrm{TL} / \mathrm{m}^{2}\right)$} & 11.57 \\
\hline \multicolumn{3}{|c|}{ Kalınlık $11.5 \mathrm{~cm}$ (IV. Bölge) $\left(T L / \mathrm{m}^{2}\right)$} & 16.63 \\
\hline
\end{tabular}

Tablo 7. Geleneksel mantolama ve yardımcı malzemeleri 2019 yılı birim fiyatları (Unit price of traditional thermal insulation and supplementary materials for 2019)

\begin{tabular}{|l|c|}
\hline \multicolumn{1}{|c|}{ Malzeme } & Birim fiyat (KDV'li) \\
\hline EPS (16 dansite, karbonlu) & $672 \mathrm{TL} / \mathrm{m}^{3}$ \\
\hline XPS (40 dansite) & $785 \mathrm{TL} / \mathrm{m}^{3}$ \\
\hline Tașyünü Levha (150 dansite) & $1025 \mathrm{TL} / \mathrm{m}^{3}$ \\
\hline Yapıștırma harcl $\left(4 \mathrm{~kg} / \mathrm{m}^{2}\right)$ & $1.3 \mathrm{TL} / \mathrm{m}^{2}$ \\
\hline Donatı filesi $(160 \mathrm{~g} / \mathrm{mtül})$ & $6 \mathrm{TL} / \mathrm{m}^{2}$ \\
\hline Dübel $\left(10 \mathrm{~cm}, 6 \mathrm{adet} / \mathrm{m}^{2}\right)$ & $1.7 \mathrm{TL} / \mathrm{m}^{2}$ \\
\hline Siva harcı $\left(5 \mathrm{~kg} / \mathrm{m}^{2}\right)$ & $8.5 \mathrm{TL} / \mathrm{m}^{2}$ \\
\hline
\end{tabular}

Geleneksel mantolama malzemeleri (EPS, XPS ve taşyünü levha) ile köpük sıvanın aynı ısı bölgeleri için $U_{D}$ değerlerini sağlayacak kalınlıklar hesaplanmıştır. Tüm ısı bölgeleri için, $19 \mathrm{~cm}$ yatay delikli tuğla duvar için UD değerlerini sağlayan (GP1) tipi köpük sıvanın U değerleri Eşitlik 7 ve Eşitlik 8'deki bağıntılar kullanılarak hesaplanmıştır. Burada; U; ısıl geçiş katsayısı, W/m² K; R, ısıl dirençtir, $\mathrm{m}^{2} \mathrm{~K} / \mathrm{W}$. GP 1 tipi köpük sıva için hesaplanan U değeri sonuçları Tablo 8'de verilmiştir.

$$
\begin{aligned}
& R=\frac{\lambda_{10}}{d} \\
& U=\frac{1}{R}
\end{aligned}
$$


Tablo 8. GP1 tipi köpük sıvanın ısı bölgelerine göre d ve U değerleri (The “U and d" values of GP 1 type plaster according to climate zone)

\begin{tabular}{|c|c|c|c|c|}
\hline Isı Bölgesi & $\mathbf{d}, \mathbf{( m )}$ & $\boldsymbol{\lambda}_{\mathbf{1 0}, \mathbf{( W} / \mathbf{m K})}$ & $\mathbf{R}, \mathbf{( \mathbf { m } ^ { 2 } \mathbf { K } / \mathbf { W } )}$ & $\left.\mathbf{U}, \mathbf{( W} / \mathbf{m}^{\mathbf{2}} \mathbf{K}\right)$ \\
\hline I & 0.045 & 0.064 & 0.70 & 1.42 \\
\hline II & 0.060 & 0.064 & 0.94 & 1.07 \\
\hline III & 0.080 & 0.064 & 1.25 & 0.80 \\
\hline IV & 0.115 & 0.064 & 1.80 & 0.56 \\
\hline \multicolumn{5}{|c|}{ R;Isll direnç, U;Isıl geçiş katsayısı } \\
\hline
\end{tabular}

Hesaplanan U değerleri esas alınarak EPS, XPS ve taşyünü levha eşdeğer kalınlıkları ( $d_{e s s}$ ) Eşitlik 9'daki bağıntı kullanılarak belirlenmiştir.

$$
d_{e \leqq}=\frac{\lambda_{10}}{U}
$$

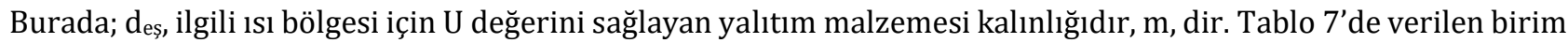
fiyatlar ve ıSı yalıtım malzemelerinin hesaplanan eşdeğer kalınlıkları (Tablo 8) esas alınarak, ıSı yalıtım malzemelerinin isı bölgelerine göre karşılaştırmalı birim maliyet oranları Şekil 7'de verilmiştir. Şekil 7 incelendiğinde, GP1 tipi köpük sıvaya göre geleneksel yalıtım malzemeleri; I. ISı bölgesi için 1.6-2.5 kat, II. ıSı bölgesi için 1.7-2.8 kat, III. ısı bölgesi için 1.8-3.1 kat, IV. ısı bölgesi için 1.9-3.5 kat daha ekonomiktir.

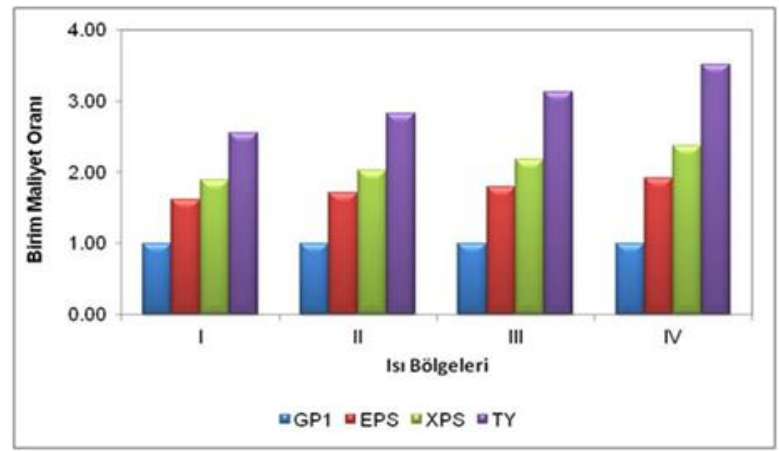

Şekil 7. Isı bölgeleri ve eșdeğer kalınlıklara göre ısı yalıtım malzemeleri birim maliyet oranları (The unit cost rates of thermal insulation materials according to climate zone and equivalent thickness)

\section{Sonuç ve Tartışma (Result and Discussion)}

Çalışma boyunca yürütülen deney ve analizlerden elde edilen bulgular aşağıda sunulmuştur.

Taze köpük sıva harcının gerçek yoğunluk değerlerinin belirlenmesi sonucunda, CK1, CK2, KP1 ve DY2 numunelerinde teorik olarak hesaplanan yoğunluk değerlerinde $\sim 40-60 \mathrm{~kg} / \mathrm{m}^{3} \mathrm{sapma}$ olmuştur.

$\checkmark 250 \mathrm{~kg} / \mathrm{m}^{3}$ kuru birim hacim kütle değerlerine, K, GP2, KP2 ve DY1 örneklerinde ulaşılmıș, GP1 örneğinde de oldukça yakın $\left(256 \mathrm{~kg} / \mathrm{m}^{3}\right)$ değerler elde edilmiștir.

$\checkmark$ En yüksek eğilme dayanımını CK1 (157 kPa) sergilemiștir. K numunesi, CK1 numunesine (148 kPa) yakın bir eğilme dayanımına sahiptir. CK1 numunesinin, nispeten daha yüksek eğilme dayanımı sergilemesi, cam küreciğin harç içerisinde hacimde daha az yer işgal etmesiyle ilişkilendirilmiştir. \%20 cam küre içeren numunenin (CK2) eğilme dayanımı \%22 civarında azalmıştır. Bu olgu eğilme dayanımında, agrega türünden daha çok matrisi olușturan harcın sorumlu olduğunu, karışımdaki hafif agrega hacmi arttıkça eğilme dayanımının azalabileceğini göstermiştir. İlave olarak, en düşük eğilme dayanımını DY numunelerinin sergilemesi, yüksek özgül yüzey alanına ve yüksek miktarda kil içeriğine bağlanmıştır.

$\checkmark$ Kütlece \%10 oranında cam küre kullanımı (CK1) basınç dayanımını \%12 oranında artırmıştır. \%10 civarında kaplı perlit kullanımında (KP1) ise kontrol numunesine göre basınç dayanımı yaklaşı aynıdır. \%10 oranında genleşmiş perlit kullanımında (GP1) dayanım \%14, \%20 oranında (GP2) ise \%25 civarında azalmıștır. \%10 oranında diyatomit kullanımında (DY1) \%24, \%20 oranında (DY2) ise \%40 dayanım kaybı gözlenmiştir.

$\checkmark$ Hedeflenen $\geq 500 \mathrm{kPa}$ basınç dayanım değerine hiçbir numunede ulaşılamamış, TS EN 998-1 standardında alt sınır olan CS1 (0.4-2.5 MPa) koşulu sağlanamamıştır.

$\checkmark$ Isll iletkenlikte öngörülen $\left(\lambda_{10-k u r u}\right) \leq 0.065 \mathrm{~W} / \mathrm{mK}$ sınır değeri K, GP1, GP2 ve DY1 numunelerinde sağlanmış, diğerlerinde öngörülen sınır değerin üstünde kalmıştır. 
$\checkmark$ Köpük sıva numunelerinin ısıl iletkenlik katsayılarının $\left(\lambda_{10 \text {-kuru }}\right)$ kullanılan hafif agrega türünden daha çok, kuru birim hacim kütleleri $\left(\rho_{\mathrm{m}}\right)$ ile yakından ilişkili olduğunu ortaya konulmuş, bu ilişki Eşitlik 6'da verilen bağıntı ile tanımlanmıştır.

$\checkmark$ Yeni inșa edilen bir binada köpük sıvanın iç ve dıș duvarda uygulanması durumunda en az uygulama kalınlıkları I. ısı bölgesi için $2.5+2.0 \mathrm{~cm}$, II. ısı bölgesinde $3.0+3.0 \mathrm{~cm}$, III. ISı bölgesinde $4.0+4.0 \mathrm{~cm}$ ve IV. ısı bölgesinde ise $6.0+5.5 \mathrm{~cm}$ olarak belirlenmiştir.

$\checkmark$ Isı bölgelerine göre K tipi köpük sıvanın (tahmini) birim fiyatı $~ 5-13 \mathrm{TL} / \mathrm{m}^{2}$, GP1 tipi köpük sıvanın ise $\sim 6.5-$ $16.5 \mathrm{TL} / \mathrm{m}^{2}$ aralığında hesaplanmıștır.

$\checkmark$ Köpük sıvanın ısı bölgelerine göre belirlenen U değerleri esas alınarak, EPS, XPS ve taş yünü levhanın eșdeğer kalınlıkları hesaplanmış, birim fiyatlar ve hesaplanan eşdeğer kalınlıklar kullanılarak, ıSı yalıtım malzemelerinin farklı ısı bölgeleri için birim maliyetleri karşılaştırılmıştır. K tipine göre daha yüksek birim maliyete sahip olan GP1 tipi köpük sıvanın birim maliyeti $\sim 145 \mathrm{TL} / \mathrm{m}^{3}$ tür. İşçilik hariç, uygulama birim fiyatları ise I., II., III. ve IV. ısı bölgelerinde sırasıyla 21, 23, 26, 31 TL/m² dir. GP1 tipi köpük sıva ile karşılaştırıldığında, geleneksel yalıtım malzemeleri; I. ısı bölgesi için 1.6-2.5 kat, II. ısı bölgesi için 1.7-2.8 kat, III. ısı bölgesi için 1.8-3.1 kat, IV. ısı bölgesi için 1.9-3.5 kat, daha pahalıdır.

Çimento esaslı köpük sıvanın hammaddeleri bol ve geleneksel yalıtım malzemelerine göre çok daha ekonomiktir. Ayrıca kullanılan tüm hammaddeleri yerli kaynaklara dayanmaktadır. Ülkemizin tüm ısı bölgelerinde bu hammaddeler kolaylıkla temin edilebilir. Ayrıca polipropilen elyaf hariç bileșiminde organik bir malzeme içermemesi ve elyaf oranının da (kütlece \%0.5) çok düșük olması, çimento esaslı köpük sıvanın A1 sınıfı yanmaz malzeme kategorisinde yer alması için yeterlidir. Bu durum çimento esaslı köpük sıvayı, taş yünü/camyünü ve mineral esaslı diğer dış cephe mantolama malzemelerine de önemli bir alternatif yapmaktadır.

\section{Teşekkür (Acknowledgement)}

Bu çalışma TÜBİTAK 118M091 nolu TÜBİTAK projesi tarafından desteklenmiştir. Yazarlar TÜBİTAK'a desteklerinden dolayı teşekkür ederler.

\section{Çıkar Çatışması (Conflict of Interest)}

Yazarlar tarafından herhangi bir çıkar çatışması beyan edilmemiştir. No conflict of interest was declared by the authors.

\section{Kaynaklar (References)}

Akbulut M., 2018. Hazır Isı Yalıtım Sıvalarının Mühendislik Özelliklerinin Belirlenmesi ve Uygunluk Değerlendirmesi, SDÜ Fen Bilimleri Enstitüsü, Yüksek Lisans Tezi, Isparta.

Barbero S., Marco Dutto M., Ferrua C., Pereno A., 2014. Analysis on existent thermal insulating plasters towards innovativeapplications: Evaluation methodology for a real cost-performance comparison, Energy and Buildings 77 (2014) 40-47.

Binaların Yangından Korunması Hakkında Yönetmelik, Resmi Gazete, Sayı 26735, 19 Aralık 2007.

Davraz M, Gündüz L, Başpınar E., 2011. Lightweight Aggregated Foam Plaster for Thermal Insulation in Buildings, Journal of Engineering Science and Design, Vol:1 No:3 pp.150-155, 2011

Dylewski R. , Adamczyk J., 2014. The comparison of thermal insulation types of plaster with cement plaster, Journal of Cleaner Production, 83 (2014) 256-262.

GÖLTAŞ AŞ, 2019. Şubat Ayı Çimento Kalite Kontrol Raporu, Isparta.

Mercan, H., 2016. Yalıtım Sektöründe Pazar Araştırması ve Pazarlama Stratejilerinin İncelenmesi, Anadolu Üniversitesi, Fen Bilimleri Enstitüsü, Yüksek Lisans Tezi, Eskişehir.

Türkiye İMSAD Yapı Sektörü 2017 Raporu -Yalıtım Malzemeleri, 2018.

Isı Yalıtımı Yol Haritası. https://webdosya.csb.gov.tr/db/meslekihizmetler/ustmenu/ustmenu1009.pdf Erişim:08.05.2019

Ünal Ö., TMMOB Makine Mühendisleri Odası Ankara Subesi Enerji Komisyonu https://www.mmo.org.tr/sites/default/files/gonderi_dosya_ekleri/0f0c65cbf947d1c_ek.pdf

Yaman Ö., Şengül Ö., Selçuk H., Çalıkuş O., Kara İ.,Erdem Ş., Özgür D., (İMO Yapı Malzemeleri Komisyonu), 2015. Türkiye Mühendislik Haberleri Sayı 60 - 487.

XPS Türkiye, 2019. http://www.xpsturkiye.org/sayfa.asp?ID=132

Zach J., Hela R., Sedlmajer M., Hroudova J., 2013. Development of Thermal Insulation Plasters for Insulating and Sanitation of Building Constructions, IACSIT International Journal of Engineering and Technology, Vol. 5, No. 3, June 2013

TS 825. Binalarda Isı Yalıtım Kuralları, TSE, Ankara, 2008.

TS EN 1015-1. Kâgir harcı - Deney yöntemleri - Bölüm 18: Sertleşmiş harcın kapiler etkiden kaynaklanan su emme katsayısının tayini, TSE, Ankara, 2004.

TS EN 1015-6. Kâgir harcı - Deney metotları - Bölüm 6: Taze harcın boşluklu birim hacim kütlesinin tayini, TSE, Ankara, 2000.

TS EN 1015-10. Kâgir harcı-Deney metotları- Bölüm 10: Sertleşmiş harcın boşluklu kuru birim hacim kütlesinin tayini, TSE, Ankara, 2001. 
TS EN 1015-18. Kâgir harcı - Deney yöntemleri - Bölüm 18: Sertleşmiş harcın kapiler etkiden kaynaklanan su emme katsayısının tayini, TSE, Ankara, 2004.

TS EN 1097-6. Agregaların mekanik ve fiziksel özellikleri için deneyler Bölüm 6: Tane yoğunluğu ve su emme oranının tayini, TSE, Ankara, 2002.

TS EN 12667. Yapı malzemeleri ve mamullerinin ısıl performansı-Mahfazalı sıcak plaka ve ısı akış sayacı metotlarıyla ısıl direncin tayini-Yüksek ve orta ısıl dirençli mamuller, TSE, Ankara, 2003. 